\title{
Performance and chemical composition of three Echinochloa grasses over short term experiment
}

\author{
Mamdouh S. Serag, Abdel Hamid A. Khedr, Gaber M. Abogadallah, Heba E. Shaaban* \\ Botany Department, Faculty of Science, Damietta University, Damietta, Egypt
}

Received: 15 December 2013 / Accepted: 09 February 2014

*Corresponding author: (Fax: +20.57.2403868, email: hbshaban_152@yahoo.com)

\begin{abstract}
Three weedy grasses, Echinochloa crus-galli (L.) P. Beauv. Echinochloa colona (L.) Link. and Echinochloa stagnina (Retz.) P. Beauv. were grown for four months in the greenhouse of Botany Department, Faculty of Science at New Damietta to examine the effect of age on plant biomass, ash, proteins, total carbohydrates, lipids and fiber content. Plants were collected from the field and replanted in greenhouse, with the same age and size. Biomass and ash content increased by increasing the age in E. colona and E. stagnina but increased in E. crus-galli till the fourth harvest then decreased. Protein, crude lipid and crude fiber content were decreased gradually by the increase of the age, in the three species throughout the progressive harvests. By the increase of the age total carbohydrates increased in E. crus-galli and E. colona but remained largely unchanged in E. stagnina. The crude fiber was a relatively high in E. crus-galli and E. colona but this was not good for forage use of the grass. The amount of PEPC and Rubisco protein was higher in $E$. stagnina than in E. crus-galli and E. colona and this lead to increase in plant biomass of $E$. stagnina than E. crus-galli and E. colona. It is recommended using E. stagnina as fodder additives due to its high content of protein and biomass and low fiber content.

The obtained results will be useful for the optimum managing strategy of these three grasses as invasive weeds in field crop as well as use them as a source of natural forage in particular in summer.
\end{abstract}

Keywords: Ash, Biomass, Carbohydrates, Echinochloa, Fibers, Forage, Lipids PEPC, Rubisco

\section{Introduction}

Echinochloa is a cosmopolitan genus belonging to Subfamily Panicoideae of the family Poaceae comprised of 20 to 25 species [1]. Although considered a weed in many agricultural systems, it is also valued by wildlife managers as a food source for waterfowl [2]. The genus Echinochloa includes serious weeds in agriculture being the third and fourth most important weeds in the world [3,4]. Echinochloa crus-galli (L.) Beauv. is a $\mathrm{C} 4$ weed that grows in paddy fields and distributed worldwide. It has adapted to temperate regions and anaerobic conditions such 
as rice fields and wetlands, but it is also used for reclamation of saline soil especially in Egypt [5]. The broad ecological adaptation, such as the ability to mimic rice, quick germination, rapid growth and abundant seed production, make it a successful weed [6]. E. crus-galli includes many sub-species and varieties. Echinochloa colona, is a vigorous $\mathrm{C} 4$ annual species, is one of the world's most serious grass weeds in rice $[7,4]$. More than 60 countries have reported it as a weed problem in 35 crops, including rice, maize (Zea mays L.), sorghum (Sorghum bicolor L.), cotton (Gossypium hirsutum L.), and peanuts (Arachis hypogea L.) [7]. E. colona is an example of crop mimicry because it closely resembles rice at the seedling stage and is sometimes unintentionally transplanted into fields together with the crop. By the time the weed can be easily recognized by farmers and removed, crop yield losses may already be unavoidable [7]. E. colona had been reported to reduce yield of direct-seeded rice by as much as $76 \%$ [8]. Echinochloa stagnina, is a C4 plant, a perennial grass, it presents as weeds in deepwater paddies and river channels $[9,10]$.

Nutritive value of forage refers to its chemical composition, digestibility and the nature of digested products [11,12]. The amount of forage consumed by the animal is very important, as it affects total nutrient intake and therefore the animal's response. The efficiency of ruminant production systems based on forages as the main source of protein and energy is strongly dependent on forage maturity, which is considered a primary factor decreasing its nutritional quality [13]. These modifications are well evident in forages at different stages of development (e.g. vegetative vs. reproductive or mature). Age and the prevailing environmental conditions may also affect the growth and nutritive value of the used grass. Variation in growth patterns, dry matter accumulation and tiller production [14].

The highest known productivity in natural vegetation is for a $\mathrm{C} 4$ perennial grass which achieves about of $100 \mathrm{t}$ (dry matter) $\mathrm{ha}^{-1}$ year $^{-1}$ $[15,16]$. Some of the world's most productive crops and pasture, such as maize (Zea mays), sugarcane (Saccharum officinarum), sorghum (Sorghum bicolor), Bermuda grass (Cynodon dactylon), and rhodes grass (Chlorisgayana) are C4 plants. In addition, the most troublesome weeds like nutgrass, crabgrass and barnyard, are also C4 species. Although $\mathrm{C} 4$ plants represent only a small portion of the world's plant species, accounting for only $3 \%$ of the vascular plants, they contribute about $20 \%$ to the global primary productivity because of the highly productive C4- grass-lands [17].

The objective of the present study was to examine the effect of age on plant biomass, ash, proteins, total carbohydrates, lipids and fiber content of the three weedy grasses in the coastal area of Damietta.

\section{Materials and methods}

\section{Studied species}

Echinochloa crus-galli is an erect to decumbent, often branched at base, tufted, stout annual, graminoid; up to $3 \mathrm{ft}$. $(100 \mathrm{~cm})$ tall or more, fibrous roots, culms often branching at base, and branching culms ascending from decumbent branches; sometimes rooting at lower culms nodes, culms stout, up to $60 \mathrm{in}$. $(50-150 \mathrm{~cm})$ high, glabrous, nodes slightly swollen [18-22].

Echinochloa colona is a tufted, erect to spreading and semi-prostrate, annual graminoid; up to 16 in. $(60 \mathrm{~cm})$ tall or more, fibrous roots, culms freely branching at base and lower nodes, culms $8-16$ in. $(20-60 \mathrm{~cm})$ or more high, glabrous or nodes pubescent [18-23].

Echinochloa stagnina is an annual or perennial, coarse, often succulent grass which floats in deep water or creeps with rhizomes and stolons, to $2 \mathrm{~m}$ long, readily and sprouts at nodes, stems up to about $1 \mathrm{~m}$ long under non-flooded conditions and elongating up to $2 \mathrm{~m}$ in flooded areas, under flooded conditions, the stem trails on the surface of the water but the leaves and inflorescence are held in an upright position above the water $[18,24,25]$.

\section{Experimental design}

The study was conducted using a randomized complete block design with 3 replicates, 9 blocks represent all treatments, the area of each block approximately $0.5 \mathrm{~m}^{2}$. The abovementioned grasses were collected from the natural habitat and replanted in green house in the third week of May 2011, the age of the plant was one month before beginning the experiment in both species E. crus-galli and E. colona but in E. stagnina similar cuts of 3 internodes are planted. Nitrogen fertilizer was applied a sure a in the third week of experiment. The first harvest began after one month for two species E. crus-galli and E. colona 
and after two months for E. stagnina. The other harvest was taken monthly till the end of experiment.

\section{Chemical Analysis}

E. crus-galli, E. colona and E. stagnina shoots were harvested and oven-dried at $65 \mathrm{C}^{\circ}$ for $72 \mathrm{hr}$. Biomass was calculated as dry weight per plant. Dried shoots were used for chemical analysis.

Dried shoot were ground to pass a $1 \mathrm{~mm}$ sieve and stored in airtight containers prior to chemical analysis. Total ash was determined by igniting at $550^{\circ} \mathrm{C}$ for $2 \mathrm{~h}$. Protein content of dry powdered plant material was determined according to the method of Bradford [26]; while, carbohydrates were determined according to the method of Schortemeyer et al. [27]. Crude lipids and crude fibers were estimated according to the method of Nesamvuni et al. [28].

\section{Measurement of PEPC and Rubisco}

The protein content of fresh plant material was determined according to the method of Bradford [26].

\section{SDS-PAGE of protein for PEPC and Rubisco quantification}

Proteins were resolved as described by Laemmlli [29] using the BioRad Mini Protean 3 (BioRad laboratories, Hercules, CA, USA). The resolving gel contained $11 \%$ acrylamide and the stacking gel contained 5\% acrylamide. Proteins from $3 \mathrm{mg}$ leaf fresh weight were loaded onto each lane. The proteins were resolved at $100 \mathrm{~V}$ for $90 \mathrm{~min}$. The gels were stained with brilliant blue R-250 (BioRad) and then destained with 20\% methanol, scanned and used for PEPC and Rubisco quantification.

\section{Statistical analysis}

One-way ANOVA-LSD was performed by entering the data into two computer programs SPSS 18.0 and CoStat 6.311.

\section{Results}

Dry weight of E. colona and E. stagnina increased but in E. crus-galli it increased until the fourth harvest then decreased in the last one, the highest dry weight was found in the fourth harvest of E. stagnina (115.16 $\mathrm{g}$ plant $^{-1}$ ) and the lowest one was found in the first harvest of $E$. crus-galli (6.34g plant $\left.{ }^{-1}\right)$ (Fig. 1).

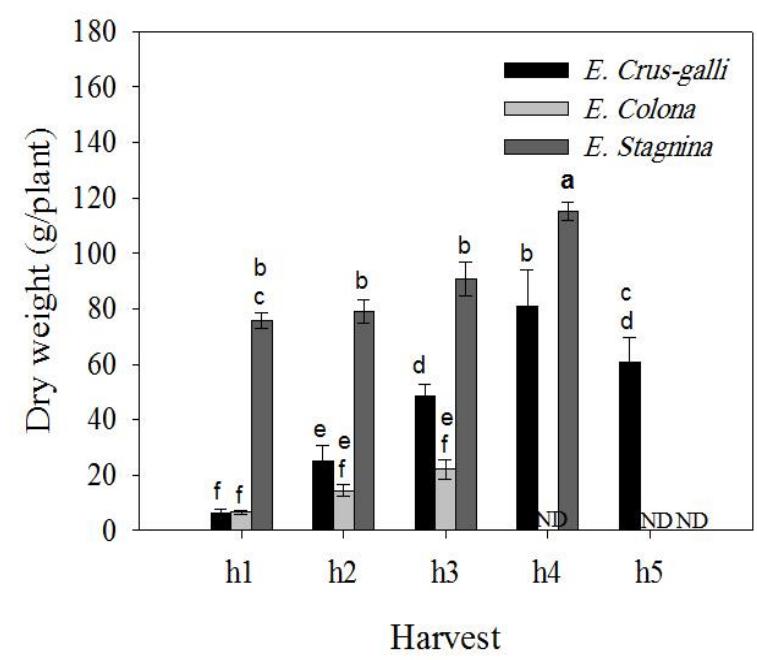

Fig. 1. Changes in dry biomass over monthly harvests of E. crus-galli, E. colona and E. stagnina.h1 (55 days), h2 (80 days), h3 (105 days), h4 (130 days), h5 (156 days), (ND) not detected. Data is mean \pm SE. Bars labeled with different letters are significantly different at $p<0.05$.

Ash content was increased by increasing the age of both E. colona and E. stagnina but in $E$. crus-galli it increased in the third harvest then decreased in the fourth and the fifth harvest, the highest ash content was found in the fourth harvest of E. stagnina (19.67\%), the lowest value was observed in the first harvest of E. stagnina (11\%) (Fig. 2).

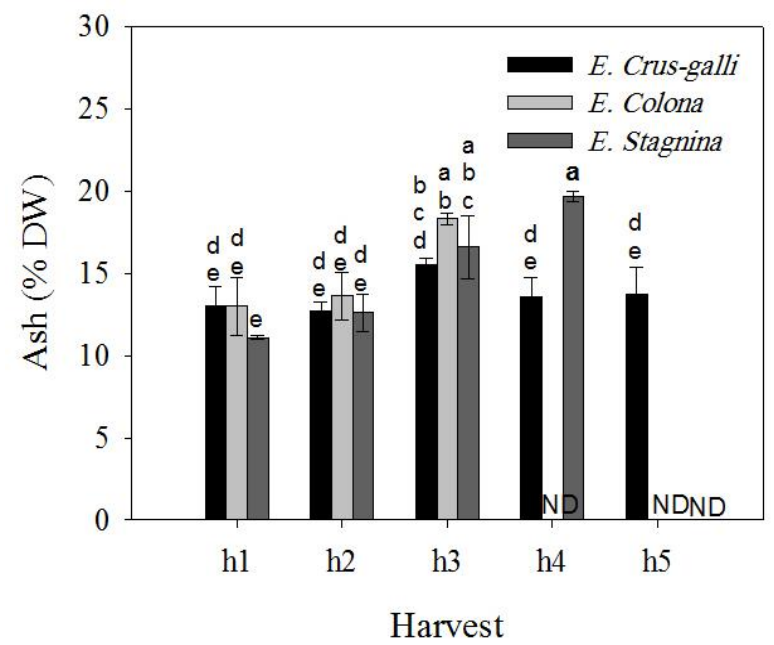

Fig. 2. Changes in ash content over monthly harvests of E. crus-galli, E. colona and E. stagnina. h1 (55 days), h2 (80 days), h3 (105 days), h4 (130 days), h5 (156 days), (ND) not detected. Data is mean \pm SE. Bars labeled with different letters are significantly different at $p<0.05$. 
Monthly harvests indicated different changes in the chemical composition of E. crus-galli, E. colona and $E$. stagnina. Protein content decreased by increasing the age in the three plants gradually and significantly along the progressive harvests, except that in E. colona, it similar in the third harvest to the first one, the highest protein content was observed in the first harvest of E. crus-galli $\left(266.43 \mathrm{mg} \mathrm{g}^{-1}\right)$ and the lowest one was found in the fourth harvest of $E$. stagnina (83.23 $\mathrm{mg} \mathrm{g}^{-1}$ ) (Fig. 3).

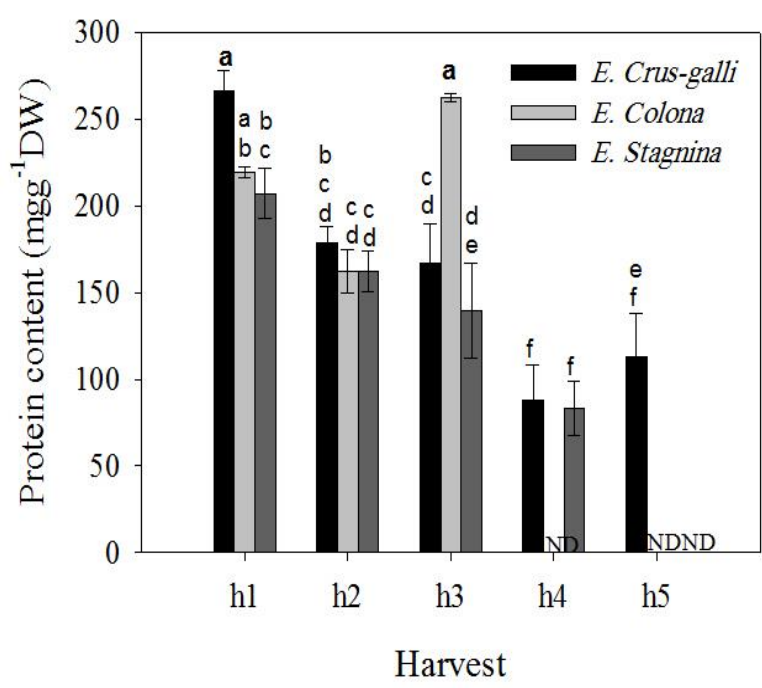

Fig. 3. Changes in protein content over monthly harvests of E. crus-galli, E. colona and E. stagnina. h1 (55 days), h2 (80 days), h3 (105 days), h4 (130 days), h5 (156 days), (ND) not detected. Data is mean \pm SE. Bars labeled with different letters are significantly different at $p<0.05$.

By increasing the age, total carbohydrates of E. crus-galli and E. colona increased but remained largely unchanged in E. stagnina. The highest total carbohydrate content (Fig. 4) was found in the third harvest of E. stagnina (2.2 $\mathrm{mg}$ $\left.\mathrm{g}^{-1}\right)$ and the lowest one was observed in the first harvest of E. crus-galli $\left(0.76 \mathrm{mg} \mathrm{g}^{-1}\right)$. The crude lipids content decreased by increasing the age of E. colona, but in E. crus-galli and E. stagnina where it decreased by increasing the age then increased in the last harvest (Fig. 5). The highest crude lipid content was found in the fourth harvest of E. stagnina (3.23\%) and the lowest one was observed in the fourth harvest of $E$. crus-galli $(0.78 \%)$.

Crude fibers decreased by increasing the age of plants in E. crus-galli, but not in E. colona and $E$. stagnina where it decreased in the second harvest then increased in the last harvest than the first. Highest crude fibers was found in the third harvest (Fig. 6) of E. colona (81.3\%) and the lowest one was found in the second harvest of $E$. stagnina $(36.9 \%)$. The amount of PEPC protein in E. stagnina was higher than that in E. crusgalli and E. colona (3-fold and 95.4\%, respectively). Rubisco protein content in $E$. stagnina was slightly higher than those of $E$. crus-galli and E. colona. The ratio of Rubisco/PEPC in E. crus-galli was higher than in $E$. colona and E. stagnina where increased by $38 \%$ and 2.58-fold, respectively (Fig.7 A\&B).

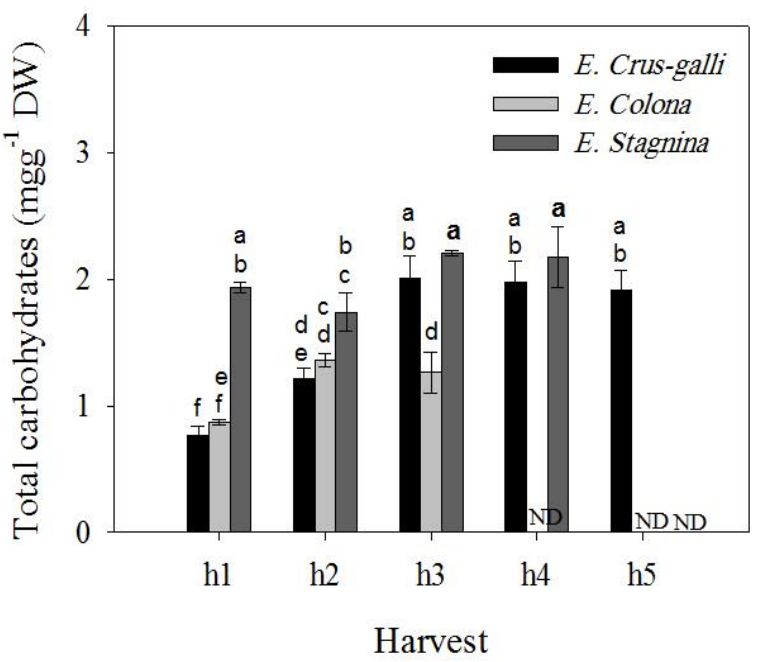

Fig. 4. Changes in carbohydrates content over monthly harvests of E. crus-galli, E. colona and E. stagnina.h1 (55 days), h2 (80 days), h3 (105 days), h4 (130 days), h5 (156 days), (ND) not detected. Data is mean \pm SE. Bars labeled with different letters are significantly different at $p<0.05$.

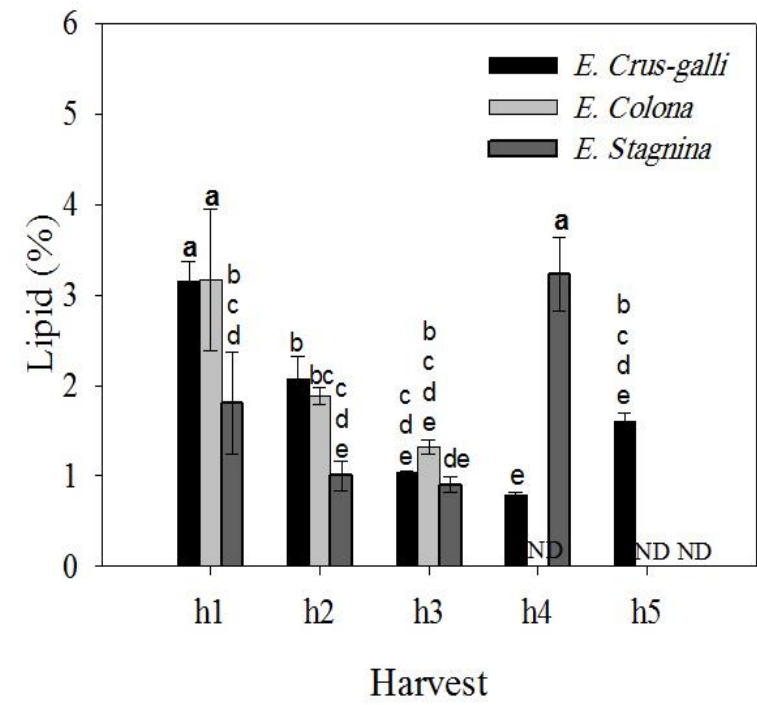

Fig. 5. Changes in crude lipid content over monthly harvests of E. crus-galli, E. colona and E. stagnina. h1 (55 days), h2 (80 days), h3 (105 days), h4 (130 days), h5 (156 days), (ND) not detected. Data is mean \pm SE. Bars labeled with different letters are significantly different at $p<0.05$. 


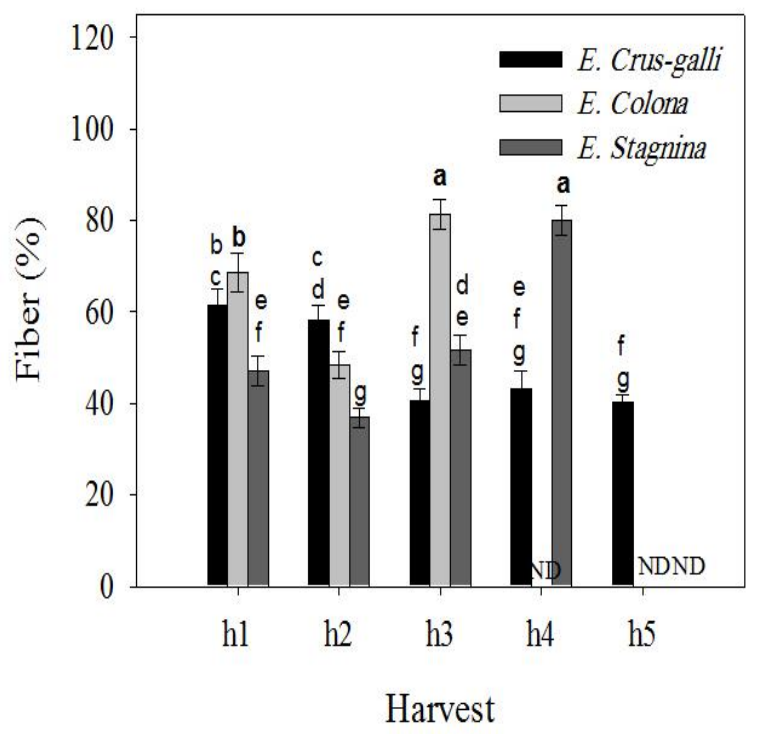

Fig. 6. Changes in fiber content over monthly harvests of E. crus-galli, E. colona and E. stagnina. h1 (55 days), h2 (80 days), h3 (105 days), h4 (130 days), h5 (156 days), (ND) not detected. Data is mean \pm SE. Bars labeled with different letters are significantly different at $p<0.05$.

\section{Discussion}

The biomass (dry weight) increased by increasing the age. In E. crus-galli it increased from $6.3 \mathrm{~g} \mathrm{plant}^{-1}$ in 55 -d old to $81 \mathrm{~g} \mathrm{plant}^{-1}$ in 130-d old. In E. colona it increased from $6.5 \mathrm{~g}$ plant ${ }^{-1}$ in 55-d old to $22 \mathrm{~g}$ plant $^{-1}$ in 105-d old. In E. stagnina it increased from $75 \mathrm{~g}^{\text {plant }}{ }^{-1}$ in $55-\mathrm{d}$ old to $115 \mathrm{~g} \mathrm{plant}^{-1} 130-\mathrm{d}$ old. The present results of dry weight in line with wheat grass (Thinopyrum paniticum) $94-780 \mathrm{~g} \mathrm{plant}^{-1}$ [30].

Ash content was increased by increasing the age of E. crus-galli, E. colona and E. stagnina. It increased in E. crus-galli, and E. stagnina from 12.9 and $11 \%$ in 55 -d old, respectively to 15.6 and $19.6 \%$ in 130-d old, respectively. And in $E$. colona it increased from $13 \%$ in 55 -d old to 18.3 $\%$ in 105-d old. Ash content of three species of Echinochloa were similar to that of Atriplex ummularia $18.1 \%$ [31], lower than that of Atriplex halimus $26.9 \%$ [32], but higher than those reported for Bromus erectus, Horedum marinum and Dactylis glomerata [33].

Total carbohydrates content increased by increasing the age of E. crus-galli, E. colona and E. stagnina. It increased in E. crus-galli and $E$. stagnina from 0.7 and $1.9 \mathrm{mg} \mathrm{g}^{-1}$ in 55-d old to about 2, $2.2 \mathrm{mg} \mathrm{g}^{-1}$ in $130-\mathrm{d}$ old. And in $E$. colona it increased from $0.8 \mathrm{mg} \mathrm{g}^{-1}$ in 55 - $\mathrm{d}$ old to $1.26 \mathrm{mg} \mathrm{g}^{-1}$ in 105-d old. Results of our study are in agree with Donaghy and Fulkerson [34] who reported that carbohydrates and its composition in grass had been correlated with its growth.
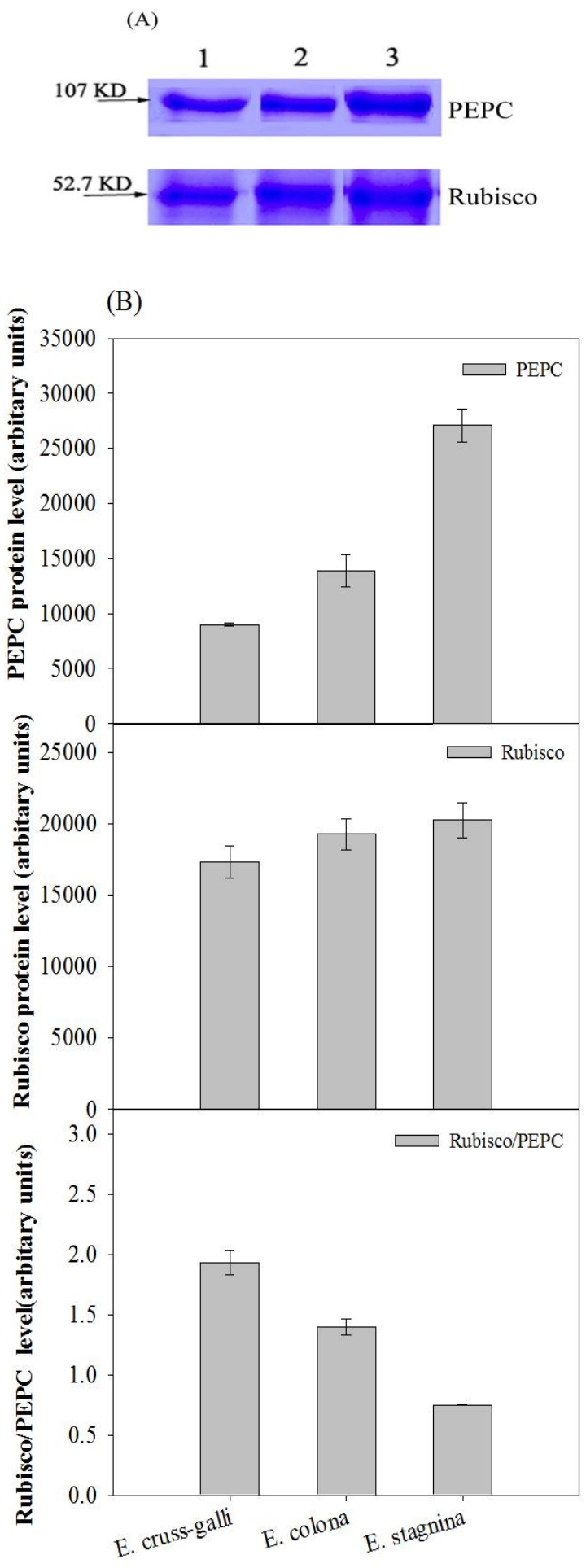

Fig. 7. (A): SDS-page shows the protein bands of PEPC and Rubisco in (1) E. cruss-galli, (2) E. colona and (3) E. stagnina. (B) Level of PEPC, Rubisco and Rubisco/PEPC in E. crus-galli, E. colona and E. stagnina. Data is mean $\pm \mathrm{SE}$. 
Also, the obtained results are in agreement with those of cocksfoot (Dactylis glomerata) where total carbohydrate increased from $101 \mathrm{mg}$ $\mathrm{g}^{-1}$ in September to $214 \mathrm{mg} \mathrm{g}^{-1}$ in November [35]. Carbohydrate content of Echinochloa sp. was lowest than that of other grasses crested wheatgrass (Agropyron cristatum) $39 \mathrm{~g} \mathrm{~g}^{-1}$ and wide leaf orchard grass (Dactylis glomerata) $23 \mathrm{~g}$ $\mathrm{g}^{-1}$ [36]. The nonstructural carbohydrates and structural polysaccharides or dietary fiber which comprises the principal components of cell walls [37] are considered to be the primary energy source for ruminant animals.

However, the fiber content of ryegrass can vary from being deficient in a vegetative state (between May and August) [38], to excess [39], after seed set or where moisture is deficient in summer. Non-structural carbohydrates are important in that they are a readily fermentable source of energy in the rumen and may also be important in synchronizing with rumen ammonia from the high protein intakes and common in cows grazing pasture [40].

Protein content was high in young plants in $E$. crus-galli and E. stagnina which began with 266 $\mathrm{mg} \mathrm{g}^{-1}, 207 \mathrm{mg} \mathrm{g}^{-1}$ in 55-d old, respectively then decreased to $113 \mathrm{mg} \mathrm{g}^{-1}, 83 \mathrm{mg} \mathrm{g}^{-1}$ in 130-d old, respectively. It increased by the increase of the age in E. colona where began with $219 \mathrm{mg} \mathrm{g}^{-1}$ in 55 -d old and reached to $262 \mathrm{mg} \mathrm{g}^{-1}$ in 105-d old. Tuna et al. [41] reported that the protein content of some grasses was between 385 and $780 \mathrm{mg} \mathrm{g}$ ${ }^{1}$, these values are not in agreement with the present study where protein content of Echinochloa sp. is between 83 and $266 \mathrm{mg} \mathrm{g}^{-1}$. The results of E. colona are in line with Minson [42] who showed that the crude protein content was lowest in mid-summer $\left(170 \mathrm{~g} \mathrm{~kg}^{-1}\right)$ and highest in autumn $\left(230 \mathrm{~g} \mathrm{~kg}^{-1}\right)$, due to the increased proportion of leaf in the forage. Results of E. crus-galli and E. stagnina agree with Lima et al. [43] which reported that hay components decreased linearly with increased growth age of Echinochloa sp. (rice grass). Also, the results agree with those in soybean $H L W-18$ where it began with $228 \mathrm{mg} \mathrm{g}^{-1}$ in July and decreased to $177 \mathrm{mg} \mathrm{g}^{-1}$ in October [44]. Protein content of Echinochloa sp was similar to those of Medicago sativa and Trifolium pretense (206, $\left.242 \mathrm{~g} \mathrm{~kg}^{-1}\right)$, respectively [45], but higher than that of Panicum maximum $177 \mathrm{~g} \mathrm{~kg}^{-1}$ [46] and Atriplex nummularia (92-131 $\mathrm{mg} \mathrm{g}^{-1}$ ) [31] and lowest than soybean $\left(310-340 \mathrm{~g} \mathrm{~kg}^{-1}\right)$ [44].

Lipid content decreased by the increase of the age in E. crus-galli and E. colona but the contrast happen in E. stagnina. In E. crus-galli began with $3.15 \%$ in 55 -d old and decreased to $1.6 \%$ in 156-d old. In E. colona it began with $3.16 \%$ in 55-d old and decreased to $1.3 \%$ in 105-d old. In E. stagnina began with $1.8 \%$ in $55-\mathrm{d}$ old and reached to $3.2 \%$ in $130-d$ old. Lipid content of Echinochloa sp highest than other in Medicago sativa, Trifolium pretense $1.3,1.8 \%$, respectively [38] and Atriplexhalimus $1.8 \%$ [32].

Fiber content was decreased by increasing the age of E. crus-galli it began with $61 \%$ in 5-d old and decreased to $40 \%$ in 156-d old. But increased in both E. colona and E. stagnina from $68.6,47 \%$ in 55-d old, respectively to $81,80 \%$ in 130 -d old, respectively. Fiber content of Echinochloa sp was higher than other in A. halimus $12.8 \%$ [32], Atriplex nummularia $2.15 \%$ [31] and soybean (HLW-18) $58.0 \%$ [44] and Panicum maxima $71.3 \%$ [46].

Protein and carbohydrates content changes in relation to season $[47,48]$, stage of growth $[49,50]$, time of day [51], soil fertility or fertilizer application rate (particularly nitrogen $(\mathrm{N})$ ) [52] and probably soil moisture status.

Photosynthetic efficiency depends on the activity of ribulose-1,5-bisphoshate carboxylase/oxygenase (Rubisco, EC 4.1.1.39). When the atmospheric $\mathrm{CO}_{2}$ decreased and $\mathrm{O}_{2}$ increased, $\mathrm{CO}_{2}$ concentration mechanisms evolved to reduce photorespiration (oxygenase activity of Rubisco) [53].

The primary $\mathrm{CO}_{2}$ fixation to PEP is catalyzed by phosphoenolpyruvate carboxylase (PEPC, EC 4.1.1.31) in mesophyll cells. $\mathrm{C} 4$ acids are transported to bundle sheath cells, where they provide $\mathrm{CO}_{2}$ to Rubisco [53,54]. Plants with $\mathrm{C} 4$ photosynthesis have advantages in extreme growth conditions such as high temperature, low water availability, high irradiation or saline soils [53].

The amount of PEPC and Rubisco protein was higher in E. stagnina than in E. crus-galli and $E$. colona and this lead to increase in plant biomass of E. stagnina than E. crus-galli and $E$. colona. The present results are in line with Piedade et al. [15] and Long [16] who reported that $\mathrm{C} 4$ plants exhibit higher photosynthetic and growth rates due to gains in the water, carbon and nitrogen efficiency uses, The highest known productivity in natural vegetation is for a $\mathrm{C} 4$ perennial grass in the central Amazon, which achieves a net production of $100 \mathrm{t}$ (dry matter) $\mathrm{ha}^{-1}$ year $^{-1}$. 


\section{Conclusion}

The present study indicated that E. crus-galli, E. colona and E. stagnina had a relatively high proteins in young plants, but because the low carbohydrate content were low in these plants, therefore, it can be considered as a source of protein as well as additives to the fodder. Crude fibers were relatively high in E. crus-galli and $E$. colona and this was not good for forage use. It is recommended to use E. stagnina as a summer fodder in marshlands where these grasses are dominant. It is a cheap source of natural forage. Furthermore, the obtained results will be useful for managing these invasive weedy grasses in field crops.

\section{References}

[1] D.A. Kovach, M.P. Widrlechner, D.M. Brenner, Variation in seed dormancy in Echinochloa and the development of a standard protocol for germination testing. Seed Sci. Technol. 38 (2010) 559-571

[2] C. Ahn, R.E. Sparks, D.C. White, A dynamic model to predict responses of millets (Echinochloa sp.) to different hydrologic conditions for the Illinois floodplain-River. River Res. Appl. 20 (2004) 485-498

[3] L.G. Holm, D.L. Plucknett, J.V. Pancho, JP. Herberger, Echinochloa crus-galli (L.) Beauv. In: The world's worst weeds (pp. 32-40). Honolulu, HI, USA: University Press of Hawaii (1977)

[4] A.N. Rao, D.E. Johnson, B. Sivaprasad, JK. Ladha, AM. Mortimer, Weed management in direct-seeded rice. Adv. Agron. 93 (2007) 153 255

[5] G.M. Abogadallah, W.P. Quick, Vegetative salt tolerance of barnyard grass mutants selected for salt tolerant germination. Acta Physiol. Plant. 31 (2009) 815-824

[6] S.C.H. Barrett, Crop mimicry in weeds. Economic Bot. 37 (1983) 255-282.

[7] L.G. Holm, D.L. Plucknett, J.V. Pancho, J.P. Herberger, The World's Worst Weeds: Distribution and Biology. Malabar, Florida: (pp 609-612) The University Press of Hawaii. (1991)

[8] B.L. Mercado, R.L. Talatala, Competitive ability of Echinochloa colonum L. against direct-seeded lowland rice. In Proceedings of the Sixth AsianPacific Weed Science Society Conference. Jakarta, Indonesia: Indonesia Asia-Pacific Weed Science Society (1977) pp. 161-165

[9] P. Michael, Distribution and taxonomy of Echinochloa- A world view with a key to the species occurring in China. In: Proceedings of the 5th Weed Science Conference of China (Kunming, China, 1994). Weed Sci. Soc. China, Kunming, China (1994) pp.161-166

[10] P. Michael, The taxonomy and distribution of Echinochloa species (barnyard grasses) in the Asian-Pacific region, with a review of pertinent biological studies. In: Proc. 18th Asian-Pacific Weed Sci. Soc. Conf. Beijing, China (2001) pp. 57-66

[11] V.A. Oyenuga, Nigeria Feeds and Feeding Stuff. Their chemistry and nutritive values. Heinemann Educational Books, Ibadan, (1987) pp. 17

[12] A.C. Naginene, O.S. Abdullah, Chemical Composition of some fodder grass of the Dares Salaam. Trop. Agric, (Trinidad) 60 (1992) 152 153.

[13] C.J. Nelson, L.E. Moser, Plant factors affecting forage quality. In: Fahey Jr., G.C. (Ed.), Forage Quality, Evaluation, and Utilization. ASA, CSSA, SSSA, Madison (1994) pp. 115-154

[14] J. Ellen, Growth yield and composition of four winter cereals 1 . Biomass, grain yield and yield formation in Netherlands. Journal of Agriculture Science, Cambridge, 41 (1993) 153-165

[15] M.T.F. Piedade, W.J. Junk, S.P. Long, The productivity of the $\mathrm{C} 4$ grass Echinochloa polystachya on the Amazon flood plain. Ecology 72 (1991)1456-1463

[16] S.P. Long, Environmental responses. In: Sage, R.F. \& Monson, R.K. (Eds.). C $_{4}$ Plant Biology. Academic Press, San Diego, USA (1999) pp. 215-249

[17] J.R. Ehleringer, T.E. Cerling, B.R. Helliker, C4 photosynthesis, atmospheric $\mathrm{CO}_{2}$ and climate. Oecologia 112 (1997) 285-299

[18] V. Tackholm, Students' Flora of Egypt; Cairo University Press, Egypt (1974) pp. 749-751

[19] T.D. Whitson, Editor; L.C. Burrill, S.A. Dewey, D.W. Cudney, B.E. Nelson, R.D. Lee, R. Parker. Weeds of the West. The Western Society of Weed Science in cooperation with the Western United States Land Grant Universities Cooperative Extension Services and the University of Wyoming. (1992) pp. 630

[20] USDA-NRCS. Conservation security program. United States Department of Agriculture, Natural Resources Conservation Service, Washington, D.C. (2006) (Online) Avaliable: www.nrcs.usda.gov/Programs/csp

[21] The Plants database United States Department of Agriculture, Natural Resources Conservation Service.Version 3.1. National Plant Data Center, Baton Rouge, LA (2001) 70874-4490 USA. http://plants.usda.gov/plants.

[22] L. Iverson, United States Department of Agriculture, Forest Service: Echinochloa crusgalli. Illinois Plant Information Network; compiled by Ketzner, D., J. Karnes. Illinois Natural History Survey, 607 E. Peabody Dr., 
Champaign, Illinois 61820 (2002)

[23] L. Iverson, United States Department of Agriculture, Forest Service: Echinochloa colona. Illinois Plant Information Network; compiled by D. Ketzner, J. Karnes. Illinois Natural History Survey, 607 E. Peabody Dr. Champaign, Illinois $61820(2002)$ www.fs.fed.us/ne/Delaware/ilpin/1132.co

[24] A.C. Smith, Flora Vitiensis nova: a new flora of Fiji. National Tropical Botanical Garden. Lawai, Kauai, Hawaii 1 (1979) pp. 494

[25] B.M. Waterhouse, A.A. Mitchell, Northern Australia Quarantine Strategy: weeds target list. Second edition. Australian Quarantine \& Inspection Service, Miscellaneous Publication 6 (1998) 98-110

[26] M.M. Bradford, A rapid and sensitive method for the quantitation of microgram quantities of protein utilizing the principle of protein-dye binding. Anal. Biochem. 72 (1976) 248-254

[27] M. Schortemeyer, P. Stamp, B. Feil, Ammonium tolerance and carbohydrate status in maize cultivars. Ann. Bot. 79 (1997) 25-30

[28] C. Nesamvuni, N. Steyn, M. Potgieter, Nutrients analysis of selected western African foods, South Afric. J. Sci. 97 (2001) 51-54

[29] E.K. Laemmlli, Cleavage of structural proteins during the assembly of the head of bacteriophage T4. Nature 227 (1970) 680-685

[30] K.P. Vogel, K.J. Moore, Forage Yield and Quality of Tall Wheatgrass Accessions in the USD A Germplasm Collection. Crop Sci. 38 (1998) 509-512

[31] A.A. Aganga, J.K. Mthetho, S. Tshwenyane, Atriplex nummularia (Old Man Saltbush): A Potential Forage Crop for Arid Regions of Botswana. Pakistan Journal of Nutrition 2 (2003) $72-75$

[32] E. Eyal, R.W. Benjamin, N.H. Tadmor,. Sheep Production on Seeded Legumes, Planted Shrubs, and Dryland Grain in a Semiarid Region of Israel. J. range manag. 28 (1975) 100-107

[33] Z. Acar, I. Ayan, O. Asci, U. Basaran, H.Mut, Biodiversity in morphological properties and nutritional values of forage grass species. J. Environ. Biol. 30 (2009) 583-589

[34] D.J. Donaghy, W.J. Fulkerson, The importance of water-soluble carbohydrate reserves on regrowth of Lolium perenne (L.). Grass Forage Sci. 52 (1997) 401-407

[35] Y. Sanada, T. Takai, T. Yamad, Ecotypic variation of water-soluble carbohydrate concentration and winter hardiness in cocks foot (Dactylis glomerata L.). Euphytica 153 (2007) 267-280

[36] K.A. Watts, Carbohydrates in Forage: What is a Safe Grass? Kentucky Equine Research, Advanced Management of Gastrointestinal and Metabolic Diseases, Lexington, KY. (2008) 1-11

[37] O. Theander, E. Westerland, P. Amah Structure and components of dietary fiber. Cereal Foods World 38 (1993) 135-141.

[38] W.J. Fulkerson, K. Slack, D.W. Hennessy, G.M. Hough, Nutrients in ryegrass (Lolium spp), white clover (Trifolium repens) and kikuyu (Pennisetum clandestinum) pastures in relation to season and stage of re-growth in subtropical environment. Aust. J. Exp. Agric. 38 (1998) 227-240

[39] R. Delagarde, J. peyraud, L. Delaby, P. Faverdin, Vertical distribution of biomass, chemical composition and pepsin- cellulase digestibility in a perennial ryegrass sward: Interaction with month of year regrowth age and time of the day. Anim. Feed Sci. Technol. 84 (2000) 49-68

[40] L.M. Trevaskis, W.J. Fulkerson, K. Nandra, Effect of time of feeding carbohydrate supplements and pasture on production of dairy cows. Livest. Prod. Sci. 85 (2004) 275-285

[41] C. Tuna, L.C. Tuna, F. Koç, Determination of nutritional value of some legume and grasses. Pak. J. Biol. Sci. 7 (2004) 1750-1753

[42] D.J. Minson, Forage in Ruminant Nutrition. Academic Press, Inc. San Diego (1990) pp. 495

[43] L.D. Lima, G.V. Kozloski, L.M. Bonnecarr`ere Sanchez, A.P. RuggiaChiesa, C.J. H“arter, G. Fiorentini, L. Oliveira, RL. CadorinJr, Effect of harvesting period on the nutritive value of rice grass (Echinochloa sp.) hay given as sole diet to lambs. Small Ruminant Res. 75 (2008) 217-225

[44] G. Zhai, Y. Shen, Y. Zhai, X. Liu, H. Jiang, Forage yield performance and nutritive value of selected wild soybean ecotypes. Can. J. Plant Sci. 88 (2008) 465-472

[45] W.J. Fulkerson, J.S. Neal, C.F. Clark, A. Horadagoda, KS. Nandra, I. Barchia, Nutritive value of forage species grown in the warm temperate climate of Australia for dairy cows: Grasses and legumes. Livestock Sci. 107 (2007) 253-264

[46] S.T. Beyene, V. Mlambo, Botanical and chemical composition of common grass species around Dip-Tank areas in semi-arid communal rangelands of Swaziland. Tropical and Subtropical Agroecosystems, 15 (2012) 143-142

[47] K.F. Smith, R.J. Simpson, R.N. Oram, K.F. Lowe, K.B. Kelly, P.M. Evans, M.O. Humphreys, Seasonal variation in herbage yield and nutritive value of perennial ryegrass (Lolium perenne L.) cultivars with high or normal herbage water-soluble carbohydrate concentrations grown in three contrasting Australian dairy environments. Aust. J. Exp. Agric. 38 (1998) 821-830

[48] C.R. Stockdale, Effect of season and the time since defoliation on the nutritive characteristics of three irrigated perennial pasture species in northern Victoria. 1. Energy, protein and fibre. Aust. J. Exp. Agric. 39 (1999) 555-565.

[49] J.F. Ayres, K.S. Nandra, A.D. Turner, The 
nutritive value of white clover at different stages of phenological maturity. Grass Forage Sci. 53 (1998) 250-259

[50] W.J. Fulkerson, K. Slack, E. Havilah, The effects of defoliation interval and height on growth and herbage quality of kikuyu grass (Pennisetum clandestinum). Trop. Grassl. 33 (1999) 138-145. www.fs.fed.us/ne/Delaware/ilpin/1133.co

[51] E. Lindgren, J.E. Lindberg, Influence of cutting time and $\mathrm{N}$ fertilization on the nutritive value of timothy. 1 Crude protein content, metabolisable energy and energy value determined in vivo versus in-vitro. Swed. J. Agric. Res. 18 (1998) $72-83$
[52] M. Reeves, W.J. Fulkerson, R.C. Kellaway, Forage quality of kikuyu (Pennisetum clandestinum): the effect of time of defoliation and nitrogen fertilizer application and in comparison with perennial ryegrass (Lolium perenne). Aust. J. Agric. Res. 47 (1996) 13491359

[53] R.F. Sage, The evolution of C4 photosynthesis, New Phytol.161 (2004) 341-370

[54] G.E. Edwards, V.R. Franceschi, E.V. Voznesenskaya, Single-cell C4 photosynthesis versus the dual-cell (Kranz) paradigm, Annu. Rev. Plant Biol. 55 (2004) 173-196

الأداء والتركيب الكيميائى لثلاثة أعشاب فى تجربة على المدى القصير

ممدوح سراج، عبد الحميد خضر، جابر مختار أبو جاد الله، هبة شعبان

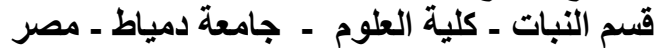

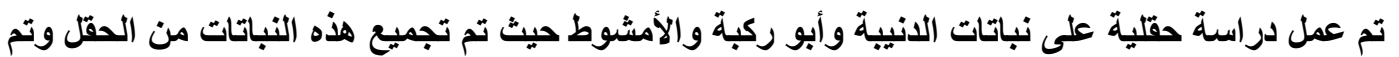

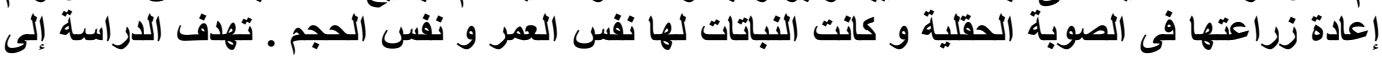

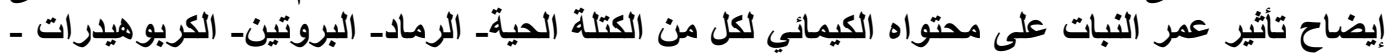

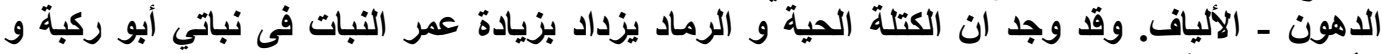

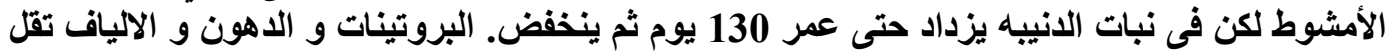

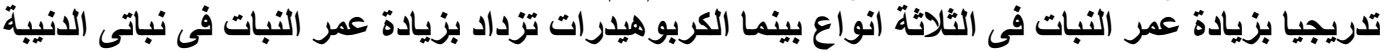

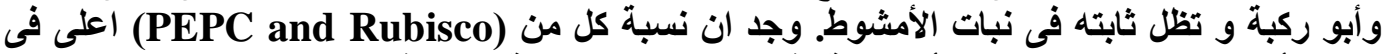

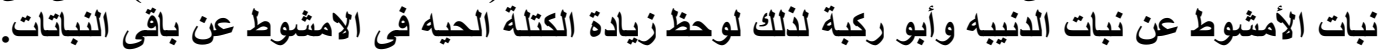

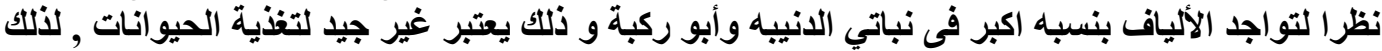

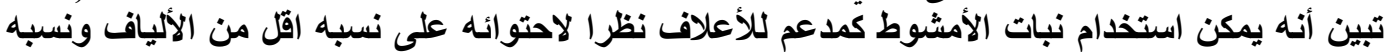

كبيرة من البروتين و الكتلة الحية. 